Regular Article

Tighlighted Leaper selected by Bditor-in-Ghief

\title{
Selective Protein Expression Changes of Leukocyte-Migration-Associated Cluster of Differentiation Antigens at the Blood-Brain Barrier in a Lipopolysaccharide-Induced Systemic Inflammation Mouse Model without Alteration of Transporters, Receptors or Tight Junction-Related Protein
}

\author{
Kazuki Sato, Masanori Tachikawa, ${ }^{* \dagger}$ Michitoshi Watanabe, Yasuo Uchida, and Tetsuya Terasaki \\ Division of Membrane Transport and Drug Targeting, Graduate School of Pharmaceutical Sciences, Tohoku \\ University; 6-3 Aramaki, Aoba, Sendai 980-8578, Japan. \\ Received November 29, 2018; accepted March 7, 2019
}

Leukocyte migration across the blood-brain barrier (BBB) is an important step in the progression of brain dysfunction in systemic inflammation. The purpose of this study was to identify the key regulatory molecule(s) at the BBB among the cluster of differentiation (CD) antigens involved in leucocyte migration in lipopolysaccharide (LPS)-induced systemic inflammation based on their absolute protein expressions. Here, we identified the absolute expression levels of $17 \mathrm{CD}$ antigens in isolated brain capillaries (Bcap) of LPS-administered mice. Among them, the expression levels of CD54 and CD106 were dramatically increased in LPS-administered mice compared to the control by 6.21- and 3.67-fold, respectively. In peripheral blood mononuclear cells, the expression levels of CD11a/CD18, the counter-receptor for CD54, were similar to those of CD54 in Bcap of LPS-administered mice. On the other hand, the expression level of CD49d, part of CD29/ CD49d complex, which is the counter-receptor for CD106, was under the limit of quantification. It is thus likely that CD54 at the BBB is predominantly involved in promoting leukocyte migration across the BBB in systemic inflammation. The expression levels of CD9, CD49c and CD97, which are thought to be involved in cell-to-cell interaction, were decreased by $40-60 \%$ in Bcap of LPS-administered mice. In contrast, the expression levels of 9 transporters, 2 receptors, and 1 tight junction-related protein in Bcap of LPS-administered mice were essentially unchanged compared to the control. These results suggest that enhancement of leucocyte migration in systemic inflammation involves dynamic changes of $C D$ antigens without alterations of other major functional molecules.

Key words blood-brain barrier; leukocyte migration; quantitative protein atlas; systemic inflammation

\section{INTRODUCTION}

Leukocyte migration across the blood-brain barrier (BBB), which consists of brain capillary endothelial cells linked by complex tight junctions, is an important step in the progression of brain dysfunction during inflammatory diseases such as sepsis ${ }^{1,2)}$ and multiple sclerosis. ${ }^{3)}$ Accumulating evidence has shown that leukocyte migration involves cluster of differentiation (CD) antigens, such as integrins and selectins, which mediate the sequential processes of leukocytes rolling on endothelial cells, activation of leukocytes, leukocyte-endothelial cell adhesion and transmigration of leucocytes across endothelial cells. ${ }^{4,5)}$ Therefore, inhibition of the CD antigens involved in the leukocyte-endothelial cell interactions would be an effective strategy to prevent pathological progression mediated by leukocyte migration across the BBB. Systemic inflammation drives BBB changes via systemic-derived or brain-derived inflammatory mediators and induces recruitment of various types of leukocytes including lymphocytes, neutrophils and monocytes across the BBB., ${ }^{1,6-10)}$ On the other hand, multiple sclerosis is an autoimmune disease of the central nervous system in which regional inflammatory reactions

${ }^{\dagger}$ Present address: Graduate School of Biomedical Sciences, Tokushima University; 1-78-1 Shomachi, Tokushima 770-8505, Japan. in the brain and spinal cord recruit leukocytes. ${ }^{3,11,12)}$ In animal experimental models such as sepsis and multiple sclerosis, leukocyte migration has been suppressed by inhibiting CD

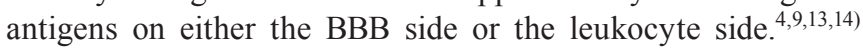
Consequently, $\mathrm{CD}$ antigens involved in leucocyte-endothelial interaction are considered to be promising druggable targets.

Natalizumab, a humanized monoclonal antibody directed against the cell adhesion molecule $\alpha 4$-integrin (CD49d) on leukocyte plasma membrane, has the ability to inhibit the leukocyte migration in relapsing multiple sclerosis. ${ }^{15)}$ However, natalizumab is thought to decrease normal immune protection by suppressing leukocyte function, leading to severe adverse effects such as progressive multifocal leukoencephalopathy (PML). ${ }^{16)}$ Other monoclonal antibody drugs that target leukocyte membrane molecules, such as efalizumab and rituximab, also cause PML. ${ }^{16)}$ We hypothesized that these adverse effects might be avoided by selecting $\mathrm{CD}$ antigens on endothelial cells as molecular targets for inhibiting leukocyte migration.

As a first step in evaluating this strategy, it is necessary to establish criteria for selecting a suitable target molecule(s) among the $\mathrm{CD}$ antigens on endothelial cells. The best target would be a molecule that makes a major contribution to the functional enhancement of leukocyte-endothelial cell interactions. Previous reports have shown that the expression levels of multiple $\mathrm{CD}$ antigens such as CD62E/E-selectin, ${ }^{17)}$ 
CD62P/P-selectin, ${ }^{17,18)}$ CD54/intracellular adhesion molecule-1 (ICAM-1), ${ }^{9,19)}$ CD106/vascular cell adhesion molecule 1 $(\text { VCAM-1 })^{19,20)}$ are increased in brain endothelial cells of a lipopolysaccharide (LPS)-induced systemic inflammation mouse model and/or experimental autoimmune encephalomyelitis (EAE) mouse, which is an animal model of multiple sclerosis. Thus, CD antigens that are abundantly expressed and/or highly induced in brain capillaries (Bcap) exposed to conditions favoring leukocyte migration such as systemic inflammation and multiple sclerosis could be promising inhibitory targets. In other words, measuring the absolute protein expression levels is useful to uncover intra-molecular and inter-molecular differences in the abundance of $\mathrm{CD}$ antigens in Bcap and/or leukocytes under normal and pathological conditions, and may be helpful for identifying optimum therapeutic options. However, the absolute levels of CD antigens in endothelial cells and leukocytes have not yet been determined or compared between normal and disease conditions.

We have previously established LC-MS/MS-based quantitative targeted absolute proteomics (QTAP) with in silico selection of the peptide sequences to be quantified, and this technology has enabled us to prepare quantitative protein atlases of membrane transporters, receptors and tight junction related-proteins at the normal $\mathrm{BBB}$ in mouse, rat, monkey, marmoset and human. ${ }^{21-25)}$ Thus, the QTAP strategy should be effective for simultaneous quantification of $\mathrm{CD}$ antigen expression amounts at the $\mathrm{BBB}$ and on leukocytes. The purpose of this study was to identify key regulatory molecules of $\mathrm{CD}$ antigens at the BBB that are involved in leukocyte migration in LPS-induced systemic inflammation and multiple sclerosis by establishing a quantitative protein atlas.

\section{MATERIALS AND METHODS}

Animals Male ddY mice (11-12 weeks old) and female C57BL/6J mice (11-15 weeks old) were purchased from SLC Japan (Shizuoka, Japan). Up to 5 mice were housed together in a plastic cage with a stainless steel lid. The mice were maintained on a 12-h light/dark cycle in a temperature-controlled environment with free access to food and water. All experiments were approved by the Institutional Animal Care and Use Committee in Tohoku University, and were performed in accordance with the guidelines of Tohoku University.

LPS-Induced Systemic Inflammation and EAE Mouse Models Leukocyte migration across the BBB is a common neurological feature in septic systemic inflammation ${ }^{1,2,9)}$ and multiple sclerosis. ${ }^{3)}$ Clarifying the expression profiles of the $\mathrm{BBB}$ functional proteins involved in leukocyte migration is important to uncover both common and specific mechanisms of neurological disease progression and to identify potential therapeutic targets at the BBB. Therefore, we focused here on LPS-administered mice as a model of systemic inflammation and EAE mice as a model of multiple sclerosis. To prepare the systemic inflammation model, LPS (Escherichia coli 0127:B8; Sigma-Aldrich, St. Louis, MO, U.S.A.) dissolved in saline was intraperitoneally administered to male ddY mice $(30 \mathrm{mg} / \mathrm{kg}$ weight) at $6 \mathrm{~h}$ prior to isolation of the Bcap. The same volume of saline was administered to control mice. EAE was induced in female C57BL/6J mice using a Hooke $\mathrm{kit}^{\mathrm{TM}} \mathrm{MOG}_{35-55} / \mathrm{CFA}$ Emulsion PTX and Hooke Control Kit ${ }^{\mathrm{TM}}$ (Hooke Laboratories, Lawrence, MA, U.S.A.) according to the manufacturer's in- structions. Behavior was evaluated at day 0 (day of immunization), and every $2 \mathrm{~d}$ after day 7 with the following symptom assignment scoring: 0 : no disease, 1: weakness of tail tonus, 2 : completely limp tail, 3 : abnormal gait, 4: complete hind limb paralysis, 5: fore limb and hind limb paralysis, 6: moribund or dead (Supplementary Fig. 1). After the induction of EAE, the first symptoms appeared between days 9 and 11, reaching a peak at around day 17, and then continuing at the same level up to day 29 (Supplementary Fig. 1). Therefore, we studied EAE mice at 14 and $29 \mathrm{~d}$ after immunization as models of the acute/progressive and chronic phases, respectively. The average scores of acute and chronic EAE mice were $2.78 \pm 0.15$ and $4.00 \pm 0.00$, respectively.

Isolation of Bcap Mouse Bcap were prepared by the nylon mesh method, as described previously. ${ }^{24}$ Briefly, 9-10 mice were anesthetized by intraperitoneal injection of pentobarbital, and transcardially perfused with phosphate-buffered saline (PBS) to remove circulating blood cells. The cerebrums were homogenized with unrotated strokes in solution $\mathrm{B}$ (101 mM NaCl, 4.6mM KCl, $5 \mathrm{mM} \mathrm{CaCl} 2,1.2 \mathrm{mM} \mathrm{KH}_{2} \mathrm{PO}_{4}$, $1.2 \mathrm{mM} \mathrm{MgSO}_{4}, 15 \mathrm{mM} \quad N$-(2-hydroxyethyl)piperazine- $N{ }^{\prime}-2$ ethanesulfonic acid (HEPES), $\mathrm{pH}$ 7.4). The homogenates were centrifuged $\left(1000 \times \boldsymbol{g}, 10 \mathrm{~min}, 4^{\circ} \mathrm{C}\right)$, and the pellet was resuspended in the same solution. An equal volume of $32 \%$ dextran (Serva Electrophoresis GmbH, Heidelberg, Germany) was added to the suspension, and the mixture was centrifuged $\left(4500 \times \boldsymbol{g}, 15 \mathrm{~min}, 4^{\circ} \mathrm{C}\right)$. The pellet was resuspended in solution A (solution B containing $25 \mathrm{mM} \mathrm{NaHCO}, 10 \mathrm{mM}$ glucose, $1 \mathrm{mM}$ pyruvate, and $5 \mathrm{~g} / \mathrm{L}$ bovine serum albumin). The suspension was successively passed through $210 \mu \mathrm{m}$ nylon mesh, $85 \mu \mathrm{m}$ nylon mesh and $20 \mu \mathrm{m}$ nylon mesh. The Bcap were collected on the $20 \mu \mathrm{m}$ nylon mesh. The collected pellet was suspended in hypotonic buffer $(10 \mathrm{mM} \mathrm{NaCl}, 1.5 \mathrm{mM}$ $\mathrm{MgCl}_{2}, 10 \mathrm{mM}$ Tris- $\mathrm{HCl}, \mathrm{pH} 7.4$ ), and sonicated to prepare whole-tissue lysate of Bcap. Protein concentration was determined by the Lowry method using DC protein assay reagent (Bio-Rad, Hercules, CA, U.S.A.). Bcap samples were stored at $-80^{\circ} \mathrm{C}$.

Isolation of Peripheral Blood Mononuclear Cells (PBMCs) PBMCs were separated from ethylenediaminetetraacetic acid (EDTA)-treated whole blood collected from 20-21 mice by density gradient centrifugation with Lympholyte-Mammal (Cedarlane Laboratories, Burlington, Canada) according to the manufacturer's instructions. The PBMCs layer were collected and washed by PBS $\left(400 \times \boldsymbol{g}, 15 \mathrm{~min}, 4^{\circ} \mathrm{C}\right)$ then resuspended in ice-cold hypotonic buffer containing $1.25 \mathrm{mM}$ phenylmethylsulfonyl fluoride, and a protease inhibitor cocktail (SigmaAldrich, St. Louis, MO, U.S.A.), and lysed by nitrogen cavitation at $600 \mathrm{psi}$ for $15 \mathrm{~min}$ at $4^{\circ} \mathrm{C}$ in a pressure vessel (Parr, Moline, IL, U.S.A.) to afford whole-cell lysate. This lysate was centrifuged $\left(10000 \times \boldsymbol{g}, 10 \mathrm{~min}, 4^{\circ} \mathrm{C}\right)$, and the supernatant was ultracentrifuged $\left(100000 \times \boldsymbol{g}, 60 \mathrm{~min}, 4^{\circ} \mathrm{C}\right)$. The resultant pellet was suspended in ice-cold suspension buffer $(250 \mathrm{mM}$ sucrose, $10 \mathrm{mM}$ Tris- $\mathrm{HCl}, \mathrm{pH} 7.4$ ) to afford crude membrane fraction. The protein concentrations of the whole-cell lysate and crude membrane fraction were determined by the Lowry method using DC protein assay reagent. Samples were stored at $-80^{\circ} \mathrm{C}$.

Peptide Sample Preparation for LC-MS/MS Analysis (Proteins to Peptides) The whole-tissue lysate obtained from Bcap, the whole-cell lysate and crude membrane fraction 
from PBMCs were subjected to lysyl endopeptidase (Lys-C) and trypsin digestion as described previously. ${ }^{22)}$ Briefly, samples were dissolved in solubilizing buffer $(7 \mathrm{M}$ guanidine hydrochloride, $10 \mathrm{mM}$ EDTA-Na, $0.5 \mathrm{M}$ Tris- $\mathrm{HCl}, \mathrm{pH} 8.5$ ) and the solubilized proteins were $S$-carboxymethylated. The alkylated proteins were precipitated with a mixture of methanol and chloroform, and the pellet was dissolved in $6 \mathrm{M}$ urea in $0.1 \mathrm{M}$ Tris- $\mathrm{HCl}(\mathrm{pH} 8.5)$. The solution was diluted 5-fold with $0.1 \mathrm{M}$ Tris- $\mathrm{HCl}$ ( $\mathrm{pH} 8.5$ ) containing $0.05 \%$ Protease-Max surfactant (Promega, Madison, WI, U.S.A.) and treated with Lys-C (Wako Pure Chemical Industries, Ltd., Osaka, Japan; enzyme/substrate ratio of $1: 100$ ) at $30^{\circ} \mathrm{C}$ for $3 \mathrm{~h}$. The Lys$\mathrm{C}$-digested sample was treated with $\mathrm{N}$-tosyl-L-phenylalanine chloromethyl ketone (TPCK)-treated trypsin (Promega; enzyme/substrate ratio of $1: 100$ ) at $37^{\circ} \mathrm{C}$ for $16 \mathrm{~h}$. The digested sample was desalted with GL-Tip ${ }^{\mathrm{TM}} \mathrm{SDB}$ and GL-Tip ${ }^{\mathrm{TM}}$ GC (GL Sciences Inc., Tokyo, Japan). The desalted sample was taken up in a solution containing $80 \%$ acetonitrile and $0.1 \%$ trifluoroacetic acid, and evaporated in a centrifugal concentrator CC-105 (TOMY; Heat Low, $1 \mathrm{~h}$ ) under vacuum. The residue was dissolved in $0.1 \%$ formic acid in water.

Synthesis of Stable-Isotope-Labeled Internal Standard Proteins for the Protein Quantification of CD Antigens To establish a QTAP-based simultaneous protein quantification system for mouse CD antigens (CD1-100), we used artificial internal standard proteins of CD-I and CD-II, in which the sequences were composed of tandemly connected target peptides of $\mathrm{CD}$ antigens. The target quantification peptides of each $\mathrm{CD}$ antigen protein were selected according to established in silico criteria ${ }^{21,22)}$ and connected tandemly. The unique reference peptides VIAPVLGR (Reference_VI, Ref_VI) and LFGPSIPLAR (Reference_LF, Ref_LF) were use $\bar{d}$ for the determination of peptide amounts, and a HAT-tag was incorporated as carboxy-terminal (C-terminal) extension for protein purification. The amino acid sequences of CD-I and CD-II proteins are shown in Supplementary Figs.
2 and 3, respectively. The CD-I and CD-II protein-encoding cDNAs were chemically synthesized by Fasmac (Kanagawa, Japan), and inserted into the plasmid pET-17b (Novagen, Darmstadt, Germany). The protein expression vectors were transfected into E. coli (BL21-CodonPlus DE3 RIPL Competent Cells, Stratagene, La Jolla, CA, U.S.A.). E. coli cells were incubated in normal lactose broth culture medium for non-isotope-labeled protein (CD-I-St and CD-II-St) synthesis, or in the C.H.L. culture medium containing ${ }^{15} \mathrm{~N}$-labeled amino acid mixture (Chlorella Industry, Tokyo, Japan) for stable isotope-labeled protein (CD-I-IS and CD-II-IS) synthesis. Protein expression was induced in the presence of $1 \mathrm{mM}$ isopropyl $\beta$-D-1-thiogalactopyranoside in the medium $\left(30^{\circ} \mathrm{C}\right.$, $3 \mathrm{~h}$ ). The synthesized CD-I and CD-II proteins were purified on HisPur ${ }^{\mathrm{TM}}$ Cobalt Spin Columns (Thermo Fisher Scientific, IL, U.S.A.) according to the manufacturer's instructions, and dialyzed in PBS. The purified protein was solubilized with $6 \mathrm{M}$ urea in $0.1 \mathrm{M}$ Tris- $\mathrm{HCl}$ ( $\mathrm{pH} 8.5$ ), $S$-carboxymethylated, and digested with Lys-C and trypsin as described in the above section on peptide sample preparation. To determine the protein amounts of CD-I and CD-II, the peptide amounts of Ref_VI and Ref_LF were quantified by using chemically synthesized non-isotope-labeled standard peptides (VIAPVLGR and LFGPSIPLAR) and stable isotope-labeled standard peptides (VIAPVLGR* and LFGPSIPLAR*, where $\mathrm{R}^{*}$ indicates labeling with ${ }^{13} \mathrm{C}$ and ${ }^{15} \mathrm{~N}$ in Ref_VI and Ref_LF). Reference peptides were monitored with four sets of selected reaction monitoring/multiple reaction monitoring (SRM/MRM) transitions (see Supplementary Table 1). The averaged value of the Ref_VI and Ref_LF peptide amounts was used as the concentration of each target peptide in each standard protein.

Quantitative Targeted Absolute Quantification (QTAP) QTAP analyses were performed according to our previous report. ${ }^{22)}$ As shown in Supplementary Tables 1 and 2, the sequences of target peptides for $\mathrm{CD}$ antigens, transporters, receptors, a tight junction-related protein and other molecules

Table 1. Protein Expression Levels of CD Antigens and Marker Proteins in Bcap and PBMCs of LPS-Administered Mice

\begin{tabular}{|c|c|c|c|c|c|c|c|c|c|}
\hline & \multicolumn{9}{|c|}{ Protein expression levels (fmol $/ \mu \mathrm{g}$ protein) } \\
\hline & \multicolumn{2}{|c|}{ Bcap } & \multirow{3}{*}{$\begin{array}{c}\text { Ratio } \\
\text { LPS/control }\end{array}$} & \multirow{2}{*}{\multicolumn{2}{|c|}{$\frac{\text { PBMCs }}{\text { Whole-cell lysates }}$}} & \multirow{3}{*}{$\begin{array}{c}\text { Ratio } \\
\text { LPS/control }\end{array}$} & \multirow{2}{*}{\multicolumn{2}{|c|}{$\frac{\text { PBMCs }}{\text { Crude membrane fractions }}$}} & \multirow{3}{*}{$\begin{array}{c}\text { Ratio } \\
\text { LPS/contro }\end{array}$} \\
\hline & \multirow{2}{*}{ Control } & \multirow{2}{*}{ LPS-administered } & & & & & & & \\
\hline & & & & Control & LPS-administered & & Control & LPS-administered & \\
\hline \multicolumn{10}{|l|}{ CD antigens } \\
\hline CD11a & U.L.Q. $(<0.497)$ & U.L.Q. $(<0.574)$ & - & $3.58 \pm 0.14$ & $2.04 \pm 0.18$ & 0.570 & $9.83 \pm 0.51$ & $17.2 \pm 0.9$ & 1.75 \\
\hline $\mathrm{CD} 18$ & $0.234 \pm 0.071$ & $0.282 \pm 0.038$ & 1.20 & $3.15 \pm 0.15$ & $2.59 \pm 0.14$ & 0.822 & $11.6 \pm 0.2$ & $15.4 \pm 0.3$ & 1.33 \\
\hline $\mathrm{CD} 29$ & $20.5 \pm 0.2$ & $22.9 \pm 0.5$ & 1.12 & $14.3 \pm 0.6$ & $9.63 \pm 0.33$ & 0.672 & $42.3 \pm 1.5$ & $64.0 \pm 1.5$ & 1.51 \\
\hline CD49d & $0.403 \pm 0.034$ & $0.360 \pm 0.034$ & 0.893 & U.L.Q. $(<0.632)$ & U.L.Q. $(<0.463)$ & - & $0.561 \pm 0.008$ & U.L.Q. $(<0.561)$ & $<0.999$ \\
\hline CD54 & $1.06 \pm 0.12$ & $6.56 \pm 0.16$ & 6.21 & U.L.Q. $(<2.72)$ & U.L.Q. $(<2.50)$ & - & U.L.Q. $(<1.83)$ & $1.84 \pm 0.12$ & $>1.00$ \\
\hline CD62E & U.L.Q. $(<0.357)$ & U.L.Q. $(<0.372)$ & - & U.L.Q. $(<2.02)$ & U.L.Q. $(<2.25)$ & - & U.L.Q. $(<0.590)$ & U.L.Q. $(<0.687)$ & - \\
\hline CD62P & U.L.Q. $(<0.872)$ & U.L.Q. $(<1.28)$ & - & N.D. & N.D. & - & U.L.Q. $(<6.15)$ & U.L.Q. (<7.39) & - \\
\hline CD102 & $4.09 \pm 0.10$ & $4.91 \pm 0.14$ & 1.20 & U.L.Q. $(<1.64)$ & U.L.Q. $(<2.16)$ & - & $1.06 \pm 0.08$ & $1.14 \pm 0.05$ & 1.07 \\
\hline CD106 & $0.503 \pm 0.041$ & $1.84 \pm 0.09$ & 3.67 & U.L.Q. $(<1.54)$ & U.L.Q. $(<1.30)$ & - & U.L.Q. $(<1.14)$ & U.L.Q. $(<1.17)$ & - \\
\hline CD162 & U.L.Q. $(<0.146)$ & U.L.Q. $(<0.157)$ & - & U.L.Q. $(<0.102)$ & U.L.Q. $(<0.0615)$ & - & $0.709 \pm 0.270$ & $0.493 \pm 0.201$ & 0.696 \\
\hline \multicolumn{10}{|l|}{ Marker proteins } \\
\hline $\mathrm{Na}^{+} / \mathrm{K}^{+}$ATPase & $26.4 \pm 0.3$ & $31.3 \pm 0.4$ & 1.18 & $1.81 \pm 0.10$ & $1.06 \pm 0.10$ & 0.588 & $5.36 \pm 0.19$ & $5.76 \pm 0.19$ & 1.07 \\
\hline$\gamma$-Gtp & $2.93 \pm 0.18$ & $3.43 \pm 0.22$ & 1.17 & U.L.Q. $(<1.83)$ & U.L.Q. $(<1.88)$ & - & U.L.Q. $(<0.701)$. & U.L.Q. $(<0.827)$ & - \\
\hline CD41 & U.L.Q. $(<0.746)$ & U.L.Q. $(<0.792)$ & - & $71.3 \pm 3.1$ & $55.6 \pm 2.5$ & 0.780 & $245 \pm 9$ & $356 \pm 14$ & 1.46 \\
\hline
\end{tabular}

Each quantitative value represents the mean \pm standard error of the mean (S.E.M.) ( $n=3-16$ transitions) obtained from three to four analyses of one whole-tissue lysate of pooled Bcap isolated from 10 mouse cerebrums, or one whole-cell lysate or crude membrane fraction of pooled PBMCs isolated from whole blood collected from $20-21$ mice. U.L.Q., Under the limit of quantification. The values in brackets represent the quantification limits (fmol/ $\mu$ g protein). N.D., Not determined. 
Table 2. Protein Expression Levels of CD Antigens and Marker Proteins in Bcap of EAE Mice

\begin{tabular}{|c|c|c|c|c|c|c|}
\hline & \multicolumn{6}{|c|}{ Protein expression levels (fmol $/ \mu \mathrm{g}$ protein) } \\
\hline & \multicolumn{2}{|c|}{ Bcap } & \multirow{2}{*}{$\begin{array}{c}\text { Ratio } \\
\text { EAE/Control }\end{array}$} & \multicolumn{2}{|c|}{ Bcap } & \multirow{2}{*}{$\begin{array}{c}\text { Ratio } \\
\text { EAE/Control }\end{array}$} \\
\hline & Control & EAE (acute phase) & & Control & EAE (chronic phase) & \\
\hline \multicolumn{7}{|l|}{ CD antigens } \\
\hline CD11a & U.L.Q. $(<1.32)$ & U.L.Q. $(<1.24)$ & - & U.L.Q. $(<0.581)$ & U.L.Q. $(<0.640)$ & - \\
\hline CD18 & $0.406 \pm 0.029$ & $0.652 \pm 0.040$ & 1.61 & $0.342 \pm 0.058$ & $0.577 \pm 0.059$ & 1.69 \\
\hline CD29 & $25.4 \pm 0.6$ & $22.4 \pm 0.5$ & 0.882 & $27.6 \pm 0.4$ & $38.9 \pm 0.4$ & 1.41 \\
\hline CD49d & $0.489 \pm 0.019$ & $0.438 \pm 0.021$ & 0.897 & $0.381 \pm 0.043$ & $0.485 \pm 0.050$ & 1.27 \\
\hline CD54 & $2.83 \pm 0.28$ & $3.04 \pm 0.28$ & 1.07 & $2.32 \pm 0.12$ & $3.53 \pm 0.16$ & 1.52 \\
\hline CD62E & U.L.Q. $(<0.179)$ & U.L.Q. $(<0.153)$ & - & U.L.Q. $(<0.388)$ & U.L.Q. $(<0.429)$ & - \\
\hline CD62P & U.L.Q. $(<1.95)$ & U.L.Q. (<2.04) & - & U.L.Q. $(<1.10)$ & U.L.Q. $(<1.38)$ & - \\
\hline CD102 & $4.96 \pm 0.10$ & $3.75 \pm 0.10$ & 0.756 & $5.55 \pm 0.14$ & $6.53 \pm 0.19$ & 1.18 \\
\hline CD106 & $1.01 \pm 0.06$ & $0.985 \pm 0.075$ & 0.975 & $0.687 \pm 0.032$ & $0.904 \pm 0.043$ & 1.32 \\
\hline CD162 & U.L.Q. $(<0.131)$ & U.L.Q. $(<0.124)$ & - & U.L.Q. $(<0.203)$ & U.L.Q. $(<0.181)$ & - \\
\hline \multicolumn{7}{|l|}{ Marker proteins } \\
\hline $\mathrm{Na}^{+} / \mathrm{K}^{+}$ATPase & $33.2 \pm 1.0$ & $27.5 \pm 0.8$ & 0.829 & $29.7 \pm 0.5$ & $37.4 \pm 0.5$ & 1.26 \\
\hline$\gamma$-Gtp & $3.77 \pm 0.09$ & $3.06 \pm 0.08$ & 0.811 & $5.09 \pm 0.17$ & $5.58 \pm 0.22$ & 1.10 \\
\hline CD41 & U.L.Q. $(<0.237)$ & U.L.Q. $(<0.218)$ & - & U.L.Q. $(<0.814)$ & U.L.Q. $(<0.871)$ & - \\
\hline
\end{tabular}

Each quantitative value represents the mean \pm S.E.M. ( $n=6-16$ transitions) obtained from three to four analyses of one whole-tissue lysate of pooled Bcap isolated from 9-10 mouse cerebrums. U.L.Q., Under the limit of quantification. The values in brackets represent the quantification limits (fmol/ $\mu \mathrm{g}$ protein).

were selected based on the in silico criteria reported previously. ${ }^{21,22)}$ The LC-MS/MS system consisted of a NanoLC-Ultra 2D plus system (Eksigent Technologies, Dublin, CA, U.S.A.), and a TripleTOF5600 equipped with a NanoSpray III ion source (AB SCIEX, Framingham, MA, U.S.A.). The NanoLCUltra 2D plus system consisted of an analytical column $(75 \mu \mathrm{m} \times 15 \mathrm{~cm}$, ReproSil-Pur C18-AQ $3 \mu \mathrm{m} 120 \AA$, Eksigent Technologies) with or without a trap column $(200 \mu \mathrm{m} \times 6 \mathrm{~mm}$ ReproSil-Pur C18-AQ $3 \mu \mathrm{m} 120 \AA$, Eksigent Technologies). The flow rates of the trap column and the analytical column were $4 \mu \mathrm{L} / \mathrm{min}$ ( $3 \mathrm{~min}$ run-time) and $300 \mathrm{~nL} / \mathrm{min}$, respectively. Mobile phases A and B consisted of $0.1 \%$ formic acid in water and $0.1 \%$ formic acid in acetonitrile, respectively. When the NanoLC-Ultra 2D plus system consisted of an analytical column with a trap column, the gradient system was as follows: $100 \% \mathrm{~A}: 0 \% \mathrm{~B}(0-0.2 \mathrm{~min})$, a linear gradient of $100 \% \mathrm{~A}: 0 \%$ $\mathrm{B}$ to $60 \% \mathrm{~A}: 40 \% \mathrm{~B}(0.2-40 \mathrm{~min})$, increased to $0 \% \mathrm{~A}: 100 \%$ B (40-41 min), maintained at $0 \%$ A: $100 \%$ B (41-50 min), reduced to $100 \% \mathrm{~A}: 0 \% \mathrm{~B}(50-50.1 \mathrm{~min})$, and then maintained at $100 \% \mathrm{~A}: 0 \% \mathrm{~B}(50.1-80 \mathrm{~min})$. When the NanoLC-Ultra 2D plus system consisted of an analytical column without a trap column, the gradient system was as follows: $100 \%$ $\mathrm{A}: 0 \% \mathrm{~B}(0-0.2 \mathrm{~min})$, a linear gradient of $100 \% \mathrm{~A}: 0 \% \mathrm{~B}$ to $50 \% \mathrm{~A}: 50 \% \mathrm{~B}(0.2-50 \mathrm{~min})$, increased to $0 \% \mathrm{~A}: 100 \% \mathrm{~B}$ (50-51 min), maintained at $0 \% \mathrm{~A}: 100 \% \mathrm{~B}(51-60 \mathrm{~min})$, reduced to $100 \% \mathrm{~A}: 0 \% \mathrm{~B}(60-60.1 \mathrm{~min})$, and then maintained at $100 \%$ A : 0\% B (60.1-70 min). Other conditions were described previously. ${ }^{26)}$ The SRM/MRM transitions of each peptide were set as shown in Supplementary Table 1 for QTAP with the chemically synthesized internal standard peptides and in Supplementary Table 2 for QTAP with the artificial internal standard proteins CD-I-IS and CD-II-IS. $1 \mu \mathrm{g}$ protein of each sample was subjected to LC-MS/MS analysis. For absolute quantification of the $\mathrm{CD}$ antigens using the CD-I and CD-II proteins, digested CD-I-IS or CD-II-IS protein-derived peptides equivalent to $100 \mathrm{fmol}$ were spiked in the digested Bcap samples ( $1 \mu \mathrm{g}$ protein). The mixed samples were desalted with
GL-Tip $^{\mathrm{TM}}$ SDB and GL-Tip ${ }^{\mathrm{TM}}$ GC (GL Sciences Inc., Tokyo, Japan). The samples were dissolved in $0.1 \%$ formic acid in water, and analyzed as described above. Calibration curves were prepared with various amounts (0-100 fmol) of peptides derived from CD-I-St and CD-II-St, and $100 \mathrm{fmol}$ peptides derived from CD-I-IS and CD-II-IS. The protein expression levels were calculated as the average of 2-16 values obtained from two to four SRM/MRM transitions in one to four analyses. A peak was defined as positive when the peak area was greater than 1000 counts, and the peaks derived from the different product ions were detected at the same retention times as those of the internal standard peptides. If no positive peaks were observed or a positive peak was detected in only one SRM/MRM transition in one to four measurements, the protein expression level was defined to be under the limit of quantification (U.L.Q.). The value of the U.L.Q. was calculated according to our previous report. ${ }^{27)}$

\section{RESULTS}

QTAP Analysis of Adhesion Molecules with Chemically Synthesized Internal Standard Peptides in Bcap and/or PBMCs of LPS-Induced Systemic Inflammation and EAE Mouse Models Tables 1 and 2 summarize the protein expression levels of adhesion molecules of CD11a, CD18, CD29, CD49d, CD54, CD62E, CD62P, CD102, CD106, and CD162, which are well-established as leukocyte-brain endothelial cell interaction-related CD antigens, ${ }^{4,5)}$ as well as several markers of Bcap and PBMCs of LPS-administered mice and the control (Table 1), and Bcap of EAE and control mice (Table 2). There were over 10 -fold differences among the expression levels of CD18, CD29, CD49d, CD54, CD102 and CD106 in Bcap of LPS-administered mice and the control (Table 1 and Supplementary Fig. 4), while the levels of CD11a, CD62E, CD62P and CD162 were the U.L.Q. The expression levels of CD54 and CD106 were dramatically increased in Bcap of LPS-administered mice compared to the control mice by 6.21 - 
Table 3. Protein Expression Levels of CD Antigens in Bcap of LPSAdministered Mice Determined by Using CD-I-IS and CD-II-IS-Derived Internal Standard Peptides

\begin{tabular}{lccc}
\hline \hline & \multicolumn{2}{c}{ Protein expression levels (fmol/ $\mu$ g protein) } \\
\cline { 2 - 4 } & Control & LPS-administered & Ratio LPS/control \\
\hline CD9 & $10.9 \pm 0.1$ & $5.79 \pm 0.10$ & 0.533 \\
CD26 & $1.88 \pm 0.03$ & $1.66 \pm 0.08$ & 0.879 \\
CD31 & $3.25 \pm 0.16$ & $3.11 \pm 0.11$ & 0.958 \\
CD49a & $9.56 \pm 0.31$ & $6.93 \pm 0.15$ & 0.725 \\
CD49c & $1.46 \pm 0.22$ & $0.862 \pm 0.165$ & 0.589 \\
CD49f & $5.92 \pm 0.22$ & $4.92 \pm 0.14$ & 0.831 \\
CD71 & $6.68 \pm 0.20$ & $5.17 \pm 0.07$ & 0.773 \\
CD82 & $0.913 \pm 0.080$ & $0.766 \pm 0.229$ & 0.839 \\
CD90 & $4.52 \pm 0.34$ & $2.49 \pm 0.16$ & 0.550 \\
CD97 & $0.436 \pm 0.031$ & $0.177 \pm 0.074$ & 0.407 \\
CD98 & $13.0 \pm 0.6$ & $10.4 \pm 0.4$ & 0.804 \\
\hline
\end{tabular}

Each quantitative value represents the mean \pm S.E.M. $(n=3-4$ transitions $)$ in one analysis of one whole-tissue lysate of pooled Bcap isolated from 10 mouse cerebrums.

and 3.67-fold, respectively (Table 1 and Supplementary Fig. 4). In the whole-cell lysates and crude membrane fractions of PBMCs of LPS-administered mice and the control, the differences in the expression levels of CD11a, CD18, CD29, CD102, and CD162 were within 2-fold (Table 1). CD49d and CD54 were quantified only in crude membrane fraction of PBMCs of control and in LPS-administered mice, respectively (Table 1).

In contrast to the Bcap of LPS-administered mice, in the Bcap of EAE and control mice, the differences in expression levels of adhesion molecules of CD18, CD29, CD49d, CD54, CD102 and CD106 at the acute and chronic phases were all within 2-fold (Table 2).

QTAP Analysis with CD-I-IS and CD-II-IS-Derived Internal Standard Peptides in Bcap of LPS-Induced Systemic Inflammation Mice The use of biosynthesized artificial proteins composed of tandemly connected target peptides is a useful strategy for the quantitative analysis of multiple proteins by LC-MS/MS. ${ }^{28)}$ To establish quantification systems for $\mathrm{CD}$ antigens, we synthesized non-isotope-labeled proteins (CD-I-St and CD-II-St) and stable isotope-labeled proteins (CD-I-IS and CD-II-IS). By using CD-I and CD-II standard proteins, we could establish quantification systems for $51 \mathrm{CD}$ antigens (Supplementary Table 2), and firstly determined their expression levels in Bcap of control mice by QTAP. Among them, the expression levels of $11 \mathrm{CD}$ antigens (CD9, CD26, CD31, CD49a, CD49c, CD49f, CD71, CD82, CD90, CD97, and CD98) were determined (Table 3), but the $40 \mathrm{CD}$ antigens were under the limit of quantification (Table 4). Moreover, the expression levels of $11 \mathrm{CD}$ antigens were also determined in Bcap of LPS-administered mice (Table 3). The comparative results showed the expression levels of CD9, CD49c, CD90 and CD97 in LPS-administered mice were decreased by $40-60 \%$ compared to those in control mice (Table 3 and Supplementary Fig. 4).

QTAP Analysis of Transporters, Receptors, and a Tight Junction-Related Protein in Bcap and/or PBMCs of LPSInduced Systemic Inflammation and EAE Mouse Models To compare the changes in expression profiles between CD antigens and other transport systems, the protein amounts of transporters, receptors, and a tight junction-related protein
Table 4. List of CD Antigens with Expression Levels below the Limit of Quantification in Bcap of Normal Mice

\begin{tabular}{|c|c|c|c|}
\hline \multicolumn{4}{|c|}{ Limit of quantification ( $\mathrm{fmol} / \mu \mathrm{g}$ protein) } \\
\hline CD3e & 1.78 & CD42c & 0.165 \\
\hline CD3g & 2.70 & CD42d & 4.46 \\
\hline CD4 & 3.51 & CD44 & 2.51 \\
\hline CD6 & 2.18 & CD45 & 0.302 \\
\hline CD7 & 2.54 & CD46 & 0.400 \\
\hline CD10 & 5.46 & CD49b & 0.940 \\
\hline CD11c & 0.852 & CD55 & 0.557 \\
\hline CDw12 & 1.44 & CD64 & 1.61 \\
\hline CD14 & 3.66 & CD68 & 0.586 \\
\hline CD19 & 1.62 & CD69 & 1.03 \\
\hline CD20 & 0.560 & CD72 & 0.801 \\
\hline CD21 & 0.882 & CD73 & 2.25 \\
\hline CD27 & 1.06 & CD74 & 0.166 \\
\hline CD30 & 1.12 & CD79a & 0.293 \\
\hline CD32 & 0.744 & CD80 & 0.140 \\
\hline CD34 & 0.461 & CD83 & 3.53 \\
\hline CD36 & 0.245 & CD84 & 1.46 \\
\hline CD37 & 1.14 & CD86 & 3.13 \\
\hline CD39 & 0.370 & CD92 & 0.120 \\
\hline CD42b & 0.467 & CD100 & 0.166 \\
\hline
\end{tabular}

The value represents the quantification limit for each protein in Bcap of normal mice (fmol $/ \mu \mathrm{g}$ protein).

were determined in Bcap and PBMCs of LPS-administered mice and the control mice (Table 5), and in Bcap of EAE and control mice in the acute and chronic phases (Table 6). In Bcap of LPS-administered mice and the control mice, the differences were all less than 1.5-fold (Table 5 and Supplementary Fig. 5). In crude membrane fraction of PBMCs of LPSadministered mice and the control mice, the expression levels of Bcrp and Entl were respectively 2.24- and 2.74-fold greater in LPS-administered mice than in control mice, whereas the differences in the other quantified proteins were within 2-fold. In Bcap of EAE (in both the acute and chronic phases) and control mice, all of the quantified proteins showed less than 1.5-fold differences (Table 6).

\section{DISCUSSION}

The present study is the first to clarify the absolute protein expression levels of CD antigens in Bcap of LPS-induced systemic inflammation and EAE mouse models, as well as PBMCs of LPS-induced systemic inflammation mouse. Numerous studies have shown that $\mathrm{CD}$ antigens, including integrins, selectins, and cellular adhesion molecules (CAMs), are expressed in brain capillary endothelial cells and/or leukocytes. ${ }^{4,5)}$ We consider that selection of candidate therapeutic targets guided by knowledge of the absolute protein expression levels of these molecules under pathological conditions might be an effective approach to identify the most appropriate target(s) for inhibiting leukocyte migration at the BBB.

Our present results indicated that the absolute expression levels of CD54 and CD106, which are involved in leukocyteendothelial cell interaction, were dramatically increased in Bcap of LPS-administered mice compared to the control mice, among CD antigens quantified in this study (Table 1). The increased protein expression levels of CD54 and CD106 in brain 
Table 5. Protein Expression Levels of Transporters, Receptors and a Tight Junction-Related Protein in Bcap and PBMCs of LPS-Administered Mice

\begin{tabular}{|c|c|c|c|c|c|c|}
\hline & \multicolumn{6}{|c|}{ Protein expression levels (fmol/ $\mu$ g protein) } \\
\hline & \multicolumn{2}{|c|}{ Bcap } & \multirow{2}{*}{$\begin{array}{c}\text { Ratio } \\
\text { LPS/control }\end{array}$} & \multicolumn{2}{|c|}{ PBMCs (crude membrane fractions) } & \multirow{2}{*}{$\begin{array}{c}\text { Ratio } \\
\text { LPS/control }\end{array}$} \\
\hline & Control & LPS-administered & & Control & LPS-administered & \\
\hline \multicolumn{7}{|l|}{$\mathrm{ABC}$ transporters } \\
\hline Abcb1a/Mdr1a & $14.3 \pm 0.2$ & $16.8 \pm 0.3$ & 1.17 & U.L.Q. $(<0.526)$ & U.L.Q. $(<0.578)$ & - \\
\hline Abcb1b/Mdr1b & U.L.Q. (<1.59) & U.L.Q. (<1.98) & - & U.L.Q. (<1.91) & U.L.Q. (<2.77) & - \\
\hline Abcb11/Bsep & U.L.Q. $(<0.418)$ & U.L.Q. $(<0.450)$ & - & U.L.Q. $(<0.567)$ & U.L.Q. $(<0.436)$ & - \\
\hline Abcc4/Mrp4 & $0.827 \pm 0.016$ & $0.961 \pm 0.031$ & 1.16 & U.L.Q. $(<0.494)$ & U.L.Q. $(<0.609)$ & - \\
\hline Abcg2/Bcrp & $4.02 \pm 0.08$ & $3.90 \pm 0.09$ & 0.970 & $0.767 \pm 0.044$ & $1.72 \pm 0.05$ & 2.24 \\
\hline \multicolumn{7}{|l|}{ SLC transporters } \\
\hline Slc2a1/Glut1 & $123 \pm 2$ & $152 \pm 3$ & 1.23 & $0.505 \pm 0.033$ & $0.544 \pm 0.066$ & 1.08 \\
\hline Slc2a3/Glut3 & $0.460^{a)}$ & $0.424^{a)}$ & 0.921 & $15.5 \pm 0.4$ & $24.6 \pm 0.6$ & 1.59 \\
\hline Slc6a6/Taut & U.L.Q. $(<1.44)$ & U.L.Q. $(<1.42)$ & - & U.L.Q. $(<1.35)$ & U.L.Q. $(<1.53)$ & - \\
\hline Slc16a1/Mct1 & $20.7 \pm 0.5$ & $23.0 \pm 0.4$ & 1.11 & $4.03 \pm 0.35$ & $7.18 \pm 0.32$ & 1.78 \\
\hline Slc22a8/Oat3 & $0.998 \pm 0.06$ & $0.805 \pm 0.056$ & 0.807 & U.L.Q. $(<0.770)$ & U.L.Q. $(<0.894)$ & - \\
\hline Slc27a1/Fatp1 & $1.47 \pm 0.16$ & $1.72 \pm 0.27$ & 1.17 & U.L.Q. $(<2.17)$ & U.L.Q. $(<2.36)$ & - \\
\hline Slc29a1/Ent1 & $0.548 \pm 0.049$ & $0.583 \pm 0.058$ & 1.06 & $0.489 \pm 0.033$ & $1.34 \pm 0.04$ & 2.74 \\
\hline \multicolumn{7}{|l|}{ Receptors } \\
\hline Insr & $0.567 \pm 0.044$ & $0.685 \pm 0.054$ & 1.21 & $0.450 \pm 0.116$ & $0.503^{a)}$ & 1.12 \\
\hline Lrp1 & $0.531 \pm 0.051$ & $0.537 \pm 0.038$ & 1.01 & U.L.Q. $(<0.349)$ & U.L.Q. $(<0.382)$ & - \\
\hline Lrp2 & U.L.Q. $(<4.33)$ & U.L.Q. $(<4.56)$ & - & U.L.Q. $(<4.48)$ & U.L.Q. $(<5.46)$ & - \\
\hline \multicolumn{7}{|c|}{ Tight junction-related protein } \\
\hline Claudin-5 & $3.30 \pm 0.10$ & $3.82 \pm 0.11$ & 1.16 & U.L.Q. $(<1.08)$ & U.L.Q. $(<1.18)$ & - \\
\hline \multicolumn{7}{|l|}{ Other } \\
\hline Basigin & $17.3 \pm 0.4$ & $18.3 \pm 0.4$ & 1.06 & $6.25 \pm 0.23$ & $8.20 \pm 0.25$ & 1.31 \\
\hline
\end{tabular}

Each quantitative value represents the mean \pm S.E.M. ( $n=4-16$ transitions) obtained from three to four analyses of one whole-tissue lysate of pooled Bcap isolated from 10 mouse cerebrums, or one crude membrane fraction of pooled PBMCs isolated from whole blood collected from 20-21 mice. U.L.Q., Under the limit of quantification. The values in brackets represent the quantification limits (fmol/ $\mu \mathrm{g}$ protein). a) The expression levels were calculated as the average of 2 quantitative values obtained from two $\mathrm{SRM} / \mathrm{MRM}$ transitions in one analysis. Insr; insulin receptor.

Table 6. Protein Expression Levels of Transporters, Receptors and a Tight Junction-Related Protein in Bcap of EAE Mice

\begin{tabular}{|c|c|c|c|c|c|c|}
\hline & \multicolumn{6}{|c|}{ Protein expression levels (fmol $/ \mu \mathrm{g}$ protein) } \\
\hline & \multicolumn{2}{|c|}{ Bcap } & \multirow{2}{*}{$\begin{array}{c}\text { Ratio } \\
\text { EAE/control }\end{array}$} & \multicolumn{2}{|c|}{ Bcap } & \multirow{2}{*}{$\begin{array}{c}\text { Ratio } \\
\text { EAE/control }\end{array}$} \\
\hline & Control & EAE (acute phase) & & Control & EAE (chronic phase) & \\
\hline \multicolumn{7}{|l|}{$\mathrm{ABC}$ transporters } \\
\hline Abcb1a/Mdr1a & $17.7 \pm 0.5$ & $14.4 \pm 0.5$ & 0.809 & $18.8 \pm 0.5$ & $22.4 \pm 0.4$ & 1.19 \\
\hline Abcb1b/Mdr1b & U.L.Q. $(<0.572)$ & U.L.Q. $(<0.563)$ & - & U.L.Q. $(<0.811)$ & U.L.Q. $(<0.783)$ & - \\
\hline Abcb11/Bsep & U.L.Q. $(<0.111)$ & U.L.Q. $(<0.101)$ & - & U.L.Q. $(<0.0901)$ & U.L.Q. $(<0.0952)$ & - \\
\hline Abcc4/Mrp4 & $1.38 \pm 0.18$ & $1.70 \pm 0.18$ & 1.24 & $1.90 \pm 0.13$ & $2.50 \pm 0.22$ & 1.31 \\
\hline Abcg2/Bcrp & $4.34 \pm 0.10$ & $3.60 \pm 0.07$ & 0.830 & $5.19 \pm 0.09$ & $6.24 \pm 0.11$ & 1.20 \\
\hline \multicolumn{7}{|l|}{ SLC transporters } \\
\hline Slc2a1/Glut1 & $160 \pm 3$ & $135 \pm 3$ & 0.847 & $146 \pm 2$ & $195 \pm 4$ & 1.34 \\
\hline Slc2a3/Glut3 & U.L.Q. $(<0.473)$ & U.L.Q. $(<0.456)$ & - & U.L.Q. $(<0.460)$ & U.L.Q. $(<0.469)$ & - \\
\hline Slc6a6/Taut & U.L.Q. $(<1.59)$ & U.L.Q. $(<0.707)$ & - & U.L.Q. $(<0.0532)$ & U.L.Q. $(<0.352)$ & - \\
\hline Slc16a1/Mct1 & $14.0 \pm 0.3$ & $10.7 \pm 0.2$ & 0.764 & $13.5 \pm 0.3$ & $14.5 \pm 0.3$ & 1.07 \\
\hline Slc22a8/Oat3 & $0.745 \pm 0.030$ & $0.689 \pm 0.020$ & 0.925 & $1.03 \pm 0.06$ & $1.15 \pm 0.04$ & 1.12 \\
\hline Slc27a1/Fatp1 & $0.662 \pm 0.071$ & $0.532 \pm 0.071$ & 0.804 & $0.543 \pm 0.051$ & $0.749 \pm 0.053$ & 1.38 \\
\hline Slc29a1/Ent1 & $0.764 \pm 0.047$ & $0.735 \pm 0.115$ & 0.962 & $0.577 \pm 0.024$ & $0.762 \pm 0.049$ & 1.32 \\
\hline \multicolumn{7}{|l|}{ Receptors } \\
\hline Insr & $0.677 \pm 0.035$ & $0.610 \pm 0.015$ & 0.900 & $0.554 \pm 0.021$ & $0.689 \pm 0.020$ & 1.24 \\
\hline Lrp1 & $0.403 \pm 0.021$ & $0.414 \pm 0.024$ & 1.03 & $0.354 \pm 0.023$ & $0.492 \pm 0.032$ & 1.39 \\
\hline Lrp2 & U.L.Q. $(<1.42)$ & U.L.Q. $(<1.47)$ & - & U.L.Q. $(<0.967)$ & U.L.Q. $(<0.877)$ & - \\
\hline \multicolumn{7}{|c|}{ Tight junction-related protein } \\
\hline Claudin-5 & $3.28 \pm 0.15$ & $3.91 \pm 0.09$ & 1.19 & $5.96 \pm 0.15$ & $7.64 \pm 0.17$ & 1.28 \\
\hline \multicolumn{7}{|l|}{ Other } \\
\hline Basigin & $14.1 \pm 0.5$ & $9.98 \pm 0.32$ & 0.709 & $11.0 \pm 0.4$ & $12.5 \pm 0.5$ & 1.14 \\
\hline
\end{tabular}

Each value represents the mean \pm S.E.M. ( $n=6-16$ transitions) obtained from three or four analyses of one whole-tissue lysate of pooled Bcap isolated from 9-10 mouse cerebrums. U.L.Q., Under the limit of quantification. The values in brackets represent the quantification limits (fmol $/ \mu \mathrm{g}$ protein). Insr; insulin receptor. 
endothelial cells in LPS-induced systemic inflammation are consistent with previous immunohistochemical results. ${ }^{20,29)}$ It has been proposed that LPS and/or LPS-induced inflammatory cytokine (e.g. tumor necrosis factor-alpha (TNF- $\alpha)$ ) increase the expression of CD54 and CD106 via activation of the transcription factors nuclear factor-kappaB $(\mathrm{NF}-\kappa \mathrm{B})$ and activator protein 1 (AP-1) in human endothelium. ${ }^{30-34)}$ Similar mechanisms could lead to the upregulation of CD54 and CD106 in brain capillary endothelial cells of LPS-treated mice. On the other hand, the expression levels of transporters, receptors and a tight junction-related protein in Bcap of LPS-administered mice were essentially unchanged compared to the control. These results imply that leukocyte migration across the BBB in LPS-induced systemic inflammation is mediated predominantly by increased expression of migration-associated CD antigens, without dramatic alterations of other basic functional molecules at the BBB. CD54 and CD106 on brain capillary endothelial cells interact with lymphocyte function-associated antigen 1 (LFA-1; CD11a/CD18 complex) and very late antigen-4 (VLA-4; CD29/CD49d complex) on leukocytes during the adhesion process. ${ }^{5}$ ) Our present data indicate that the expression levels of both CD11a and CD18 in PBMCs (wholecell lysates) are similar to that of CD54 in Bcap (about 3-fold difference) in LPS-administrated mice (Table 1). In contrast, the expression level of CD49d in PBMCs (whole-cell lysate) was U.L.Q. in both LPS-administered mice and the control; further that in crude membrane fraction of normal PBMCs was $0.561 \mathrm{fmol} / \mu \mathrm{g}$ protein, whereas that in PBMCs of LPSadministered mice was under the quantification limit (U.L.Q. $<0.561 \mathrm{fmol} / \mu \mathrm{g}$ protein). These results suggest that the leucocyte-endothelial cell binding of CD29/CD49d complex with CD106 at the BBB of LPS-administered mice is unchanged or even suppressed, compared with control mice. Thus, it appears that inhibition of the binding of CD54 with CD11a/ CD18 would be more effective to prevent leukocyte migration across the BBB. In support of this notion, previous studies have shown that lymphocyte adhesion to, and/or transmigration across, inflammatory-cytokine-activated brain capillary endothelial cells were significantly inhibited by depletion of endothelial CD54, ${ }^{35)}$ anti-CD54, ${ }^{35,36)}$ as well as by single treatment with anti-LFA-1 (CD11a/CD18 complex) ${ }^{37}$ ) antibodies, whereas anti-CD106 ${ }^{36}$ ) and anti-VLA-4 (CD29/CD49d complex $)^{37)}$ antibodies had modest effect. Furthermore, anti-CD54 antibody reduced neutrophil accumulation in lung of cecal ligation puncture (CLP)-septic systemic inflammation mice, but anti-CD106 antibody or anti-VLA-4 (CD29/CD49d complex) antibody had no effect. ${ }^{38)}$ Interestingly, CD54-depleted mice showed not only reduced cell migration into the brain, ${ }^{9)}$ but also reduced mortality ${ }^{39)}$ in LPS-induced systemic inflammation. These lines of evidence strongly suggest that CD54 is a promising target at the BBB for inhibition of leukocyte migration in systemic inflammation.

Activation of integrins such as CD11a and CD18 on leukocytes is a crucial step of leukocyte migration across the BBB. ${ }^{37)}$ However, our present results indicate that the protein expression levels of CD11a and CD18 in PBMCs of LPSadministered mice were essentially unchanged compared to the control. The activation of integrins could be explained by the fact that the binding affinities of integrins are increased by conformation changes and clustering. ${ }^{40)}$ On the other hand, it has been reported that the activation of CAMs such as
CD54 and CD106 involves increased expression levels. ${ }^{9,19,20,41)}$ From the viewpoint of the absolute protein levels obtained in the present study, the expression of CD54 $(1.06 \mathrm{fmol} / \mu \mathrm{g}$ protein) in Bcap is less than that of CD11a/CD18 (3.58 and $3.15 \mathrm{fmol} / \mu \mathrm{g}$ protein, respectively) in PBMCs under normal conditions, whereas the expression of CD54 (6.56 fmol $/ \mu \mathrm{g}$ protein) exceeds that of CD11a/CD18 $(2.04$ and $2.59 \mathrm{fmol} / \mu \mathrm{g}$ protein, respectively) in LPS-administered mice. It is thus possible that leukocyte migration across the BBB is due at least in part to increased binding affinities of CD11a and CD18 in PBMCs, as well as the increased maximum binding capacity of CD54 due to the increased protein levels in Bcap.

QTAP with the CD-I-IS and CD-II-IS internal standard proteins allowed us to determine the expression levels of $11 \mathrm{CD}$ antigens in Bcap of LPS-administered mice and the control (Table 3). Among the detected $\mathrm{CD}$ antigens, the expressions of $\mathrm{CD} 9,{ }^{42)} \mathrm{CD} 26,{ }^{43)} \mathrm{CD} 31,{ }^{44)} \mathrm{CD} 49 \mathrm{a},{ }^{45)} \mathrm{CD} 49 \mathrm{c},{ }^{45)} \mathrm{CD} 49 \mathrm{f},{ }^{45}$ $\mathrm{CD} 71,{ }^{46)} \mathrm{CD} 82,{ }^{47)} \mathrm{CD} 97^{47)}$ and $\mathrm{CD}^{4} 8^{48)}$ at the BBB are consistent with previous findings. Although protein expression of CD90, which is predominantly expressed in brain pericytes, ${ }^{49}$ ) was detected in Bcap, it is presumably derived from brain capillary-contacting pericytes. The present results indicate that the expression levels of CD9, CD49c and CD97 are decreased by $40-60 \%$ in Bcap of LPS-administered mice (Table 3). An immunoprecipitation study has demonstrated that CD9 and CD49c would form a complex at the cell-to-cell junctions of human umbilical vein endothelial cell (HUVEC). ${ }^{50)}$ Furthermore, the direct interaction of CD9 with a tight junctionrelated protein claudin-1 was demonstrated by means of a cross-linking proteomics study. ${ }^{51)}$ We have recently reported that claudin-5 and claudin-11 are expressed at the human and rodent $\mathrm{BBB}^{52)}$ Although it is unclear whether CD9 interacts with claudin-5 or claudin- 11 at the BBB, these results imply that reduced expression of CD9 may affect the integrity of endothelial cell-to-cell junctions. The function of CD97 in BBB is still unknown, but CD97 is also expressed preferentially in E-cadherin-based adherens junctions of colonic enterocytes, and CD97 overexpression increased the structural integrity of adhesion junctions of enterocytes by promoting lateral cell-tocell interactions, which, in contrast, were weakened in CD97 knockout mice. ${ }^{53)}$ Leukocyte migration across the $\mathrm{BBB}$ is considered to occur via not only a transcellular route, but also a paracellular route. ${ }^{54,55)}$ These lines of evidence suggest that the decreased levels of CD9, CD49c and CD97 are involved in the enhancement of leucocyte migration via the paracellular route across the $\mathrm{BBB}$ in LPS-administered mice by affecting endothelial cell-to-cell interaction at the BBB.

The absolute protein expression levels determined by using CD-I-IS and CD-II-IS proteins as internal standards could be affected by incomplete trypsin digestion. However, in this study, the expression levels of CD71 (transferrin receptor 1, $6.68 \mathrm{fmol} / \mu \mathrm{g}$ protein) and CD98 (4F2hc, $13.0 \mathrm{fmol} / \mu \mathrm{g}$ protein) in Bcap of control ddy mouse determined by using CD-I and CD-II standard proteins were consistent with reported expression levels of CD71 (4.34-5.84 fmol $/ \mu$ g protein $)^{22,56)}$ and CD98 $\left(16.4-17.2 \mathrm{fmol} / \mu \mathrm{g}\right.$ protein), ${ }^{21,56)}$ determined by using chemically synthesized internal standard peptides. Thus, we think that the standard proteins would have been almost completely digested by trypsin under the conditions of the present study.

In Bcap derived from the cerebrum of the EAE model mice (in both the acute and chronic phases) and control mice, we 
did not find any dramatic difference (i.e., less than 2-fold) in $\mathrm{CD}$ antigens, transporters, receptors or a tight junction-related protein. This could be explained by the fact that the site of disease onset in the EAE mouse brain is localized, ${ }^{12)}$ and our analysis of Bcap isolated from whole cerebrum would not have detected such local protein expression changes. In support of this notion, previous reports have demonstrated that (i) the first entry of leukocytes into the central nervous system (CNS) occurs at the dorsal blood vessels of the fifth lumbar segment of the spinal cord ${ }^{57)}$ and (ii) CD54 is expressed in localized regions of EAE mouse brain. ${ }^{58)}$ It would be intriguing in future studies to determine the absolute protein expression levels of $\mathrm{CD}$ antigens in the Bcap of restricted brain regions and the spinal cord capillaries of EAE mice, in which the leucocyte migration occurred.

In conclusion, our measurements here of the absolute protein expression levels of $\mathrm{CD}$ antigens in Bcap and leukocytes suggest that $\mathrm{CD} 54$ at the $\mathrm{BBB}$ is the most promising candidate as an inhibitory target molecule for the inhibition of leukocyte-migration in systemic inflammation. Moreover, we observed decreased expression of CD9, CD49c and CD97, which are thought to be involved in cell-to-cell interaction, suggesting their involvement in leukocyte migration as well. These findings should be helpful in the development of BBBtargeting drugs to block leukocyte migration associated with CNS disorders.

Acknowledgments This study was supported in part by Grants-in-Aid from the Japanese Society for the Promotion of Science (JSPS) for Scientific Research (A) [KAKENHI: 24249011] and the grants from New Energy and Industrial Technology Development Organization (NEDO), the Takeda Science Foundation, and the Japan Agency for Medical Research and Development (AMED), Practical Research Project for Rare/Intractable Diseases. We also thank Ms. A. Niitomi and Ms. N. Handa for secretarial assistance.

Conflict of Interest The authors declare no conflict of interest.

Supplementary Materials The online version of this article contains supplementary materials.

\section{REFERENCES}

1) Michels M, Steckert AV, Quevedo J, Barichello T, Dal-Pizzol F. Mechanisms of long-term cognitive dysfunction of sepsis: from blood-borne leukocytes to glial cells. Intensive Care Med. Exp., 3, $30(2015)$

2) Stubbs DJ, Yamamoto AK, Menon DK. Imaging in sepsis-associated encephalopathy-insights and opportunities. Nat. Rev. Neurol., 9, 551-561 (2013).

3) McFarland HF, Martin R. Multiple sclerosis: a complicated picture of autoimmunity. Nat. Immunol., 8, 913-919 (2007).

4) Rossi B, Angiari S, Zenaro E, Budui SL, Constantin G. Vascular inflammation in central nervous system diseases: adhesion receptors controlling leukocyte-endothelial interactions. J. Leukoc. Biol., 89, 539-556 (2011).

5) Engelhardt B, Ransohoff RM. Capture, crawl, cross: the T cell code to breach the blood-brain barriers. Trends Immunol., 33, 579-589 (2012).

6) Wang H, Hong LJ, Huang JY, Jiang Q, Tao RR, Tan C, Lu NN,
Wang CK, Ahmed MM, Lu YM, Liu ZR, Shi WX, Lai EY, Wilcox CS, Han F. P2RX7 sensitizes Mac-1/ICAM-1-dependent leukocyteendothelial adhesion and promotes neurovascular injury during septic encephalopathy. Cell Res., 25, 674-690 (2015).

7) Comim CM, Vilela MC, Constantino LS, Petronilho F, Vuolo F, Lacerda-Queiroz N, Rodrigues DH, da Rocha JL, Teixeira AL, Quevedo J, Dal-Pizzol F. Traffic of leukocytes and cytokine upregulation in the central nervous system in sepsis. Intensive Care Med., 37, 711-718 (2011).

8) Banks WA, Niehoff ML, Ponzio NM, Erickson MA, Zalcman SS. Pharmacokinetics and modeling of immune cell trafficking: quantifying differential influences of target tissues versus lymphocytes in SJL and lipopolysaccharide-treated mice. J. Neuroinflammation, $\mathbf{9}$, 231 (2012).

9) Bohatschek M, Werner A, Raivich G. Systemic LPS injection leads to granulocyte influx into normal and injured brain: effects of ICAM-1 deficiency. Exp. Neurol., 172, 137-152 (2001).

10) Wang H, Sun J, Goldstein H. Human immunodeficiency virus type 1 infection increases the in vivo capacity of peripheral monocytes to cross the blood-brain barrier into the brain and the in vivo sensitivity of the blood-brain barrier to disruption by lipopolysaccharide. $J$. Virol., 82, 7591-7600 (2008).

11) Pierson E, Simmons SB, Castelli L, Goverman JM. Mechanisms regulating regional localization of inflammation during CNS autoimmunity. Immunol. Rev., 248, 205-215 (2012).

12) Waiczies H, Millward JM, Lepore S, Infante-Duarte C, Pohlmann A, Niendorf T, Waiczies S. Identification of cellular infiltrates during early stages of brain inflammation with magnetic resonance microscopy. PLOS ONE, 7, e32796 (2012).

13) Ransohoff RM, Kivisakk P, Kidd G. Three or more routes for leukocyte migration into the central nervous system. Nat. Rev. Immunol., 3, 569-581 (2003).

14) Yednock TA, Cannon C, Fritz LC, Sanchez-Madrid F, Steinman L, Karin N. Prevention of experimental autoimmune encephalomyelitis by antibodies against alpha 4 beta 1 integrin. Nature, 356, 63-66 (1992).

15) Polman CH, O’Connor PW, Havrdova E, Hutchinson M, Kappos L, Miller DH, Phillips JT, Lublin FD, Giovannoni G, Wajgt A, Toal M, Lynn F, Panzara MA, Sandrock AW; AFFIRM Investigators. A randomized, placebo-controlled trial of natalizumab for relapsing multiple sclerosis. N. Engl. J. Med., 354, 899-910 (2006).

16) Bohra C, Sokol L, Dalia S. Progressive multifocal leukoencephalopathy and monoclonal antibodies: a review. Cancer Contr., 24, 1073274817729901 (2017).

17) Piccio L, Rossi B, Scarpini E, Laudanna C, Giagulli C, Issekutz AC, Vestweber D, Butcher EC, Constantin G. Molecular mechanisms involved in lymphocyte recruitment in inflamed brain microvessels: critical roles for P-selectin glycoprotein ligand-1 and heterotrimeric G(i)-linked receptors. J. Immunol., 168, 1940-1949 (2002).

18) Döring A, Wild M, Vestweber D, Deutsch U, Engelhardt B. E- and P-selectin are not required for the development of experimental autoimmune encephalomyelitis in C57BL/6 and SJL mice. J. Immunol., 179, 8470-8479 (2007).

19) Dopp JM, Breneman SM, Olschowka JA. Expression of ICAM-1, VCAM-1, L-selectin, and leukosialin in the mouse central nervous system during the induction and remission stages of experimental allergic encephalomyelitis. J. Neuroimmunol., 54, 129-144 (1994).

20) Fries JW, Williams AJ, Atkins RC, Newman W, Lipscomb MF, Collins T. Expression of VCAM-1 and E-selectin in an in vivo model of endothelial activation. Am. J. Pathol., 143, 725-737 (1993).

21) Kamiie J, Ohtsuki S, Iwase R, Ohmine K, Katsukura Y, Yanai K, Sekine Y, Uchida Y, Ito S, Terasaki T. Quantitative atlas of membrane transporter proteins: development and application of a highly sensitive simultaneous LC/MS/MS method combined with novel insilico peptide selection criteria. Pharm. Res., 25, 1469-1483 (2008). 
22) Uchida $Y$, Tachikawa M, Obuchi W, Hoshi Y, Tomioka Y, Ohtsuki S, Terasaki T. A study protocol for quantitative targeted absolute proteomics (QTAP) by LC-MS/MS: application for inter-strain differences in protein expression levels of transporters, receptors, claudin-5, and marker proteins at the blood-brain barrier in ddY, FVB, and C57BL/6J mice. Fluids Barriers CNS, 10, 21 (2013).

23) Ito K, Uchida Y, Ohtsuki S, Aizawa S, Kawakami H, Katsukura Y, Kamiie J, Terasaki T. Quantitative membrane protein expression at the blood-brain barrier of adult and younger cynomolgus monkeys. J. Pharm. Sci., 100, 3939-3950 (2011).

24) Hoshi $Y$, Uchida $Y$, Tachikawa $M$, Inoue $T$, Ohtsuki $S$, Terasaki T. Quantitative atlas of blood-brain barrier transporters, receptors, and tight junction proteins in rats and common marmoset. $J$. Pharm. Sci., 102, 3343-3355 (2013).

25) Uchida Y, Ohtsuki S, Katsukura Y, Ikeda C, Suzuki T, Kamiie J, Terasaki T. Quantitative targeted absolute proteomics of human blood-brain barrier transporters and receptors. J. Neurochem., 117, 333-345 (2011).

26) Uchida Y, Zhang Z, Tachikawa M, Terasaki T. Quantitative targeted absolute proteomics of rat blood-cerebrospinal fluid barrier transporters: comparison with a human specimen. J. Neurochem., 134, 1104-1115 (2015).

27) Miyauchi E, Tachikawa M, Decleves X, Uchida Y, Bouillot JL, Poitou C, Oppert JM, Mouly S, Bergmann JF, Terasaki T, Scherrmann JM, Lloret-Linares C. Quantitative atlas of cytochrome P450, UDP-glucuronosyltransferase, and transporter proteins in jejunum of morbidly obese subjects. Mol. Pharm., 13, 2631-2640 (2016).

28) Miyauchi E, Furuta T, Ohtsuki S, Tachikawa M, Uchida Y, Sabit H, Obuchi W, Baba T, Watanabe M, Terasaki T, Nakada M. Identification of blood biomarkers in glioblastoma by SWATH mass spectrometry and quantitative targeted absolute proteomics. PLOS ONE, 13, e0193799 (2018).

29) Ramirez SH, Hasko J, Skuba A, Fan S, Dykstra H, McCormick R, Reichenbach N, Krizbai I, Mahadevan A, Zhang M, Tuma R, Son YJ, Persidsky Y. Activation of cannabinoid receptor 2 attenuates leukocyte-endothelial cell interactions and blood-brain barrier dysfunction under inflammatory conditions. J. Neurosci., 32, 4004-4016 (2012).

30) Sawa Y, Ueki T, Hata M, Iwasawa K, Tsuruga E, Kojima H, Ishikawa H, Yoshida S. LPS-induced IL-6, IL-8, VCAM-1, and ICAM-1 expression in human lymphatic endothelium. J. Histochem. Cytochem., 56, 97-109 (2008).

31) Ledebur HC, Parks TP. Transcriptional regulation of the intercellular adhesion molecule-1 gene by inflammatory cytokines in human endothelial cells. Essential roles of a variant NF-kappa B site and p65 homodimers. J. Biol. Chem., 270, 933-943 (1995).

32) Ahmad M, Theofanidis P, Medford RM. Role of activating protein-1 in the regulation of the vascular cell adhesion molecule-1 gene expression by tumor necrosis factor-alpha. J. Biol. Chem., 273, 4616-4621 (1998).

33) Sawa Y, Sugimoto Y, Ueki T, Ishikawa H, Sato A, Nagato T, Yoshida S. Effects of TNF-alpha on leukocyte adhesion molecule expressions in cultured human lymphatic endothelium. J. Histochem. Cytochem., 55, 721-733 (2007).

34) Zhou Z, Liu Y, Miao AD, Wang SQ. Protocatechuic aldehyde suppresses TNF-alpha-induced ICAM-1 and VCAM-1 expression in human umbilical vein endothelial cells. Eur. J. Pharmacol., 513, $1-8(2005)$.

35) Reiss Y, Hoch G, Deutsch U, Engelhardt B. T cell interaction with ICAM-1-deficient endothelium in vitro: essential role for ICAM-1 and ICAM-2 in transendothelial migration of T cells. Eur. J. Immunol., 28, 3086-3099 (1998).

36) Wong D, Prameya R, Dorovini-Zis K. In vitro adhesion and migration of $\mathrm{T}$ lymphocytes across monolayers of human brain microvessel endothelial cells: regulation by ICAM-1, VCAM-1, E-selectin and PECAM-1. J. Neuropathol. Exp. Neurol., 58, 138-152 (1999).
37) Male D, Rahman J, Pryce G, Tamatani T, Miyasaka M. Lymphocyte migration into the CNS modelled in vitro: roles of LFA-1, ICAM-1 and VLA-4. Immunology, 81, 366-372 (1994).

38) Laudes IJ, Guo RF, Riedemann NC, Speyer C, Craig R, Sarma JV, Ward PA. Disturbed homeostasis of lung intercellular adhesion molecule-1 and vascular cell adhesion molecule-1 during sepsis. $\mathrm{Am} . J$. Pathol., 164, 1435-1445 (2004).

39) Xu H, Gonzalo JA, St Pierre Y, Williams IR, Kupper TS, Cotran RS, Springer TA, Gutierrez-Ramos JC. Leukocytosis and resistance to septic shock in intercellular adhesion molecule 1-deficient mice. J. Exp. Med., 180, 95-109 (1994).

40) Gahmberg CG, Fagerholm SC, Nurmi SM, Chavakis T, Marchesan S, Gronholm M. Regulation of integrin activity and signalling. Biochim. Biophys. Acta, 1790, 431-444 (2009).

41) Kumasaka T, Quinlan WM, Doyle NA, Condon TP, Sligh J, Takei F, Beaudet A, Bennett CF, Doerschuk CM. Role of the intercellular adhesion molecule-1 (ICAM-1) in endotoxin-induced pneumonia evaluated using ICAM-1 antisense oligonucleotides, anti-ICAM-1 monoclonal antibodies, and ICAM-1 mutant mice. J. Clin. Invest., 97, 2362-2369 (1996).

42) Rössler K, Neuchrist C, Kitz K, Scheiner O, Kraft D, Lassmann H. Expression of leucocyte adhesion molecules at the human bloodbrain barrier (BBB). J. Neurosci. Res., 31, 365-374 (1992).

43) Hartel S, Gossrau R, Hanski C, Reutter W. Dipeptidyl peptidase (DPP) IV in rat organs. Comparison of immunohistochemistry and activity histochemistry. Histochemistry, 89, 151-161 (1988).

44) Muller WA, Ratti CM, McDonnell SL, Cohn ZA. A human endothelial cell-restricted, externally disposed plasmalemmal protein enriched in intercellular junctions. J. Exp. Med., 170, 399-414 (1989).

45) Haring HP, Akamine BS, Habermann R, Koziol JA, Del Zoppo GJ. Distribution of integrin-like immunoreactivity on primate brain microvasculature. J. Neuropathol. Exp. Neurol., 55, 236-245 (1996).

46) Jefferies WA, Brandon MR, Hunt SV, Williams AF, Gatter KC, Mason DY. Transferrin receptor on endothelium of brain capillaries. Nature, 312, 162-163 (1984).

47) Zhang Y, Chen K, Sloan SA, Bennett ML, Scholze AR, O'Keeffe S, Phatnani HP, Guarnieri P, Caneda C, Ruderisch N, Deng S, Liddelow SA, Zhang C, Daneman R, Maniatis T, Barres BA, Wu JQ. An RNA-sequencing transcriptome and splicing database of glia, neurons, and vascular cells of the cerebral cortex. J. Neurosci., 34, 11929-11947 (2014)

48) Matsuo H, Tsukada S, Nakata T, Chairoungdua A, Kim DK, Cha SH, Inatomi J, Yorifuji H, Fukuda J, Endou H, Kanai Y. Expression of a system L neutral amino acid transporter at the blood-brain barrier. Neuroreport, 11, 3507-3511 (2000).

49) Park TI, Feisst V, Brooks AE, Rustenhoven J, Monzo HJ, Feng SX, Mee EW, Bergin PS, Oldfield R, Graham ES, Curtis MA, Faull RL, Dunbar PR, Dragunow M. Cultured pericytes from human brain show phenotypic and functional differences associated with differential CD90 expression. Sci. Rep., 6, 26587 (2016).

50) Yáñez-Mó M, Alfranca A, Cabañas C, Marazuela M, Tejedor R, Ursa MA, Ashman LK, de Landazuri MO, Sánchez-Madrid F. Regulation of endothelial cell motility by complexes of tetraspan molecules CD81/TAPA-1 and CD151/PETA-3 with alpha3 beta1 integrin localized at endothelial lateral junctions. J. Cell Biol., 141, 791-804 (1998)

51) Kovalenko OV, Yang XH, Hemler ME. A novel cysteine crosslinking method reveals a direct association between claudin-1 and tetraspanin CD9. Mol. Cell. Proteomics, 6, 1855-1867 (2007).

52) Uchida Y, Sumiya T, Tachikawa M, Yamakawa T, Murata S, Yagi Y, Sato K, Stephan A, Ito K, Ohtsuki S, Couraud PO, Suzuki T, Terasaki T. Involvement of claudin-11 in disruption of blood-brain, -spinal cord, and -arachnoid barriers in multiple sclerosis. $\mathrm{Mol}$. Neurobiol., 56, 2039-2056 (2019).

53) Becker S, Wandel E, Wobus M, Schneider R, Amasheh S, Sittig D, Kerner C, Naumann R, Hamann J, Aust G. Overexpression of CD97 
in intestinal epithelial cells of transgenic mice attenuates colitis by strengthening adherens junctions. PLoS ONE, 5, e8507 (2010).

54) Winger RC, Koblinski JE, Kanda T, Ransohoff RM, Muller WA.

Rapid remodeling of tight junctions during paracellular diapedesis in a human model of the blood-brain barrier. J. Immunol., 193, 2427-2437 (2014).

55) Lutz SE, Smith JR, Kim DH, Olson CVL, Ellefsen K, Bates JM, Gandhi SP, Agalliu D. Caveolin1 is required for Th1 cell infiltration, but not tight junction remodeling, at the blood-brain barrier in autoimmune neuroinflammation. Cell Reports, 21, 2104-2117 (2017)

56) Toshi $Y$, Uchida Y, Tachikawa M, Ohtsuki S, Terasaki T. Actin filament-associated protein 1 (AFAP-1) is a key mediator in inflam- matory signaling-induced rapid attenuation of intrinsic P-gp function in human brain capillary endothelial cells. J. Neurochem., 141, 247-262 (2017).

57) Arima Y, Harada M, Kamimura D, Park JH, Kawano F, Yull FE, Kawamoto T, Iwakura Y, Betz UA, Marquez G, Blackwell TS, Ohira Y, Hirano T, Murakami M. Regional neural activation defines a gateway for autoreactive $\mathrm{T}$ cells to cross the blood-brain barrier. Cell, 148, 447-457 (2012).

58) Doerck S, Gobel K, Weise G, Schneider-Hohendorf T, Reinhardt M, Hauff P, Schwab N, Linker R, Maurer M, Meuth SG, Wiendl H. Temporal pattern of ICAM-I mediated regulatory T cell recruitment to sites of inflammation in adoptive transfer model of multiple sclerosis. PLoS ONE, 5, e15478 (2010). 